\title{
A Spivakian Reading of Alex Haley's Roots
}

\author{
Maryam Esmikhani \\ English Department, Faculty of Literature and Foreign Languages, Islamic Azad University Karaj Branch, Iran \\ E-mail: m.esmikhani@yahoo.com \\ Behzad Pourqarib (Corresponding author) \\ Department of English Language and Literature, Golestan University, Golestan, Iran \\ E-mail: Pourgharib_lit@yahoo.com
}

Received: 28-08-2015

Published: 01-03-2016
Accepted: 25-11-2015

doi:10.7575/aiac.ijalel.v.5n.2p.22
Advance Access Published: December 2015

URL: http://dx.doi.org/10.7575/aiac.ijalel.v.5n.2p.22

\begin{abstract}
The research work efforts to examine the postcolonial aspects of Alex Haley's Roots (1976) in the light of Spivakian postcolonial theories. The argument is based on post-colonial dimensions and the emphasis is put on the notions of the "Subalternity," "Strategic Essentialism", "Black Identity," and "Feeling of Otherness." These concepts used by Gayatri Chakravorty Spivak (1942) as an Indian literary theorist, philosopher and University Professor at Columbia University, describe the lower classes and the social groups who are at the margins of a society. In arguing the processes of the development of post-colonial studies, the concept of strategic essentialism plays an important role. The purpose of this study is to explore how Alex Haley constructs marginalized black voices as feeling of otherness in Roots. In mentioned work Haley emphasized that African Americans which are presented as sublaterns in the discourse of White people, have a long historical background and that not all of that history is lost, as many supposed. The aim of this paper is to trace the postcolonial theories of Spivak in the work that represents the common problems of marginalized people in different situations. In Roots, Haley depicts the ways superior class of society are suppressing and declining the rights of the lower class, and the way whites are trying to suppress blacks. It seems that in this play, by depicting the misery of African Americans, Haley is trying to say the fact that it is time that the marginalized people get a chance to speak.
\end{abstract}

Keywords: Spivakian Reading, Roots, Subalternity, Strategic Essentialism, Black Identity, Feeling of Otherness

\section{Introduction}

The research work attempts to study the postcolonial aspects of Alex Haley's Roots (1976), in the light of Spivakian postcolonial theories. Gayatri Chakravorty Spivak (1942- ) is an Indian literary theorist, philosopher and University Professor at Columbia University and "a founding member of the school's Institute for Comparative Literature and Society" (McAfee 16). She is famous for the essay "Can the Subaltern Speak?" She is also best known for her translation and introduction to Jacques Derrida's De la grammatologie. In 2012 she was awarded the 'Kyoto Prize' in Arts and Philosophy for being "a critical theorist and educator speaking for the humanities against intellectual colonialism in relation to the globalized world". (16)This paper analyses how author deals with identity of the Black American who are at the margins of society or in Spivakian's word subalterns. Roots is considered by many critics as an important work in the history of African American literature and culture. Many activists viewed Roots as a significant part of the civil rights movement, where African Americans fought for their rights. In this book Haley created "an extraordinary political, racial, social and cultural dialogue that hadn't been seen since the publication of Uncle Tom's Cabin". (Gonzales, 19)

Alexander Murray Palmer "Alex" Haley (1921 -1992) was an American writer known as the author of Roots: The Saga of an American Family (1976). He was born in Ithaca, New York, on August 11, 1921. He is an important figure in the development of his national literature. He writes to people who have lived through and have the same cultural past with them. Regarding racial attitudes, Roots had a positive impact on white prejudice due to the fact that it was written from "black perspective" (Balon 299) Alex Haley's Roots is about the life of Kunta Kinte and the generation who came after him. In this book, by drawing his own African roots, Haley tells the story of Americans of African origin. Roots is grounded on Alex Haley's family history. As Haley explains it, his forefather Kunta Kinte is kidnapped from his African village and sold into slavery, and taken to America. He tries to escape several times but finally he is caught and maimed. Later he marries Bell, his plantation's cook, and later they have a daughter name Kizzy, who is in the end sold away from them. Kizzy became pregnant by her master, and the boy becomes a cock fighter who later helps his family to gain their freedom. During the course of the story, the family witnesses important events in U.S. history, such as the Revolutionary and Civil Wars and slave rebellions. This book is a mixture of fiction, history and biography. In some parts of the story Haley found some gaps in his attempts to trace his family roots and had to fill in the blanks from his own imagination.

Although Roots is a work of fiction, Haley claimed that Kunta Kinte, the protagonist of the story was his forefather and 
his daughter named Kizzy was his great-great-great grandmother. Haley also claimed that his portrayal of life of slaves and masters in Virginia and North Carolina were based on facts which he had found through historical documents. In final chapter of the Roots he asserts:

To the best of my knowledge and of my effort, every lineage statement within Roots is from either my African or American families' carefully preserved oral history, much of which I have been able conventionally to corroborate with documents. Those documents, along with the myriad textural details of what were contemporary indigenous lifestyles, cultural history, and such that give Roots flesh have come from years of intensive research in fifty-odd libraries, archives, and other repositories on three continents.(Roots, 19)

Alex Haley as an African writer does not have a simple definition for African literature; actually he is an important figure in the development of his national literature. He writes to people who have lived through and have the same cultural past with them. Regarding racial attitudes, Roots had a positive impact on white prejudice due to the fact that it was written from "black perspective". (Balon, 299)

\subsection{Statement of the Problem}

As Spivak asserts in her famous article "Can the Subaltern Speak?" The critical nature of postcolonial theory makes it necessary to dislocate the western ways of thinking by creating space for the Subaltern, or marginalized groups of society in order to speak and produce changes to dominant discourse (Spivak, 283). Spivak, as one of the most significant figures in postcolonial study, borrows the term subaltern from Gramsci, to refer to "the unrepresented group of people in the society" (Gramsci, 55).

Spivak offers a theory of subalternity in her essay "Can the Subaltern Speak?" In this essay, she justified the limitations of the subalterns, asking "Can the Subaltern Speak?" By subaltern Spivak means "the oppressed subjects" or more generally those "of inferior rank". She adds that "In the context of colonial production, the subaltern has no history and cannot speak" (Spivak, 287).

The purpose of this study is to explore how Alex Haley constructs marginalized black voices as subaltern in Roots. In the mentioned work Haley emphasized that African Americans which are presented as Sublaterns in the discourse of White people, have a long history and that not all of that history is necessarily lost, as many believed. The aim of this paper is to trace the subalternity, strategic essentialism, black identity, and feeling of otherness in the work that represents the common problems of marginalized people in different situations. Here are some questions that the researcher is going to answer through the paper:

1. How Haley's Roots represents Subalternity?

2. How race, social classes function in the colonial and postcolonial elements of the mentioned text?

3. What are the ties of the black characters to African language and cultural practices in the mentioned play?

\section{Methodology}

postcolonialism is concerned with the responses of the colonized: "the struggle to control self-representation through the appropriation of dominant languages, discourses and forms of narratives; the struggle over the representations of place, history, race and ethnicity; and the struggle to present a local reality to a global audience"(Tyson, 419). Postcolonial criticism is "a way of reading and rereading texts of both metropolitan and colonial cultures to draw deliberate attention to the profound and inescapable effects of colonization on literary production" (Tyson, 419).

In the world of literature, post-colonial studies claims that after the Second World War "literatures in English" has replaced English and American literature. "This term includes the multicultural and multiethnic nature of works written in English" (Ashcroft, 2). Bill Ashcroft in his book, The Empire Writes Back, suggests that in the world of literary criticism, the word post-colonialism "is concerned with the world as it exists during and after the period of European imperial domination and the effect of this on contemporary literatures" (Ashcroft, 2).

There are plenty of thinkers who have talked about and developed the concept of post-colonialism, but among them are three figures that are considered as the pioneers of post-colonial theory, Homi K. Bhabha, Edward Said, and Gayatri Spivak. Young believes, "Said, Spivak and Bhabha have enabled a radical conceptualization of the relationship between nation, culture and ethnicity, which has major cultural political significance" (Young, 1)

Spivak's main involvement to Postcolonial theory came with her specific definition of the term subaltern. Spivak also introduced terms such as 'essentialism', 'strategic essentialism'. (Sharp, chapter 6) She also is best known for her contemporary cultural and critical theories to challenge the "legacy of colonialism" and the way readers engage with literature and culture. She often focuses on the cultural texts of "those who are marginalized by dominant western culture: the new immigrant; the working class; women; and other positions of the subaltern." (Sharp Chapter 6 and Spivak, 62-63)

In critical theory and postcolonialism, subaltern is the social group who are socially, politically and geographically outside of the "hegemonic power structure" of the colony and of the "colonial homeland" (Young, 2).

In the 1980s the Indian literary critic Spivak introduced the terms strategic essentialism to describe the social functions of postcolonialism. Strategic essentialism refers to a strategy that nationalities, ethnic groups or minority groups can use to present themselves. Although strong differences may exist between members of these groups, and amongst 
themselves they engage in continuous debates, it is sometimes advantageous for them to temporarily "essentialize" themselves and to bring forward their group identity in a simplified way to achieve certain goals, or to oppose the levelling impact of global culture. (Ashcroft et al, 159)

Spivak developed Foucault's term epistemic violence to define the destruction of non-Western ways of observing the world. Theoretically, epistemic violence definitely relates to women, whereby the "Subaltern [woman] must always be caught in translation, never [allowed to be] truly expressing herself", because the colonial power's destruction of her culture pushed to the social margins her non-Western ways of perceiving, understanding, and knowing the world. (Sharp, 8)

According to Spivak, epistemic violence occurred through the marginalization of certain voices within Western discourses. These voices belong to the "subaltern." Spivak believes that the West imposes a false universal value system on the subaltern. So instead of accepting the values of the unique culture as valid or reliable, the practices will be described as barbaric, strange, immoral, and totally harmful to the cultural and social progress of the people. (The Archeology of Knowledge, 41). She uses the British ban on Sati (burning widows alive with their dead husbands) as her example.

\section{Discussion}

\subsection{Negro-Americans as Subalterns}

According to Spivak "although the term 'subaltern' conventionally denotes an inferior military rank, it is more generally used as 'a name for the general attribute of subordination in society', often expressed in terms of gender and caste "(Spivak, 93). Social division is recognized all over the world in all times and it is based on various features, such as wealth, religion, gender, race and so on. The most important division is based on race and color of skin.

By treatment of black characters as the subaltern in his novel, Haley shows their pitiable position in the white society. Roots is a story about the right of black people in a biased white society and the subsequent of the division of people through the race and the color of their skins which pollutes the beauty of the natural world. As it is indicated in the novel, we know that black people or the so-called Negroes as subalterns are denied the basic human rights in many ways, but Kunta is a man who cannot understand all these irrational rules and regulations for slaves.

All through the history, Negro-Americans as subalterns were treated like outsiders within the white society. Because of their black race and culture, they were forced to leave their homeland for slavery in the United States. During the course of story as we can see, slavery has different definitions among people. In chapter 16 Lamin asks Kunta about the meaning of slave.

"What are slaves?" Lamin asked Kunta one afternoon. Kunta grunted and fell silent. Walking on, seemingly lost in thought, he was wondering what Lamin had overheard to prompt that question. Kunta knew that those who were taken by toubob became slaves, and he had overheard grownups talking about slaves who were owned by people in Juffure. But the fact was that he really didn't know what slaves were. (Roots, 69)

As we can see Alex Haley's Roots is the history of black slaves whose identities were stolen from them. People have been always measured as servants and inferior to whites because of the white's power in America through centuries over the blacks. As it is mentioned in the story a man with a dark skin was identified as being a slave.

"Fa, what are slaves?" Omoro just grunted at first, saying nothing, and for several minutes moved about in the grove, inspecting the trunks of different palms. "Slaves aren't always easy to tell from those who aren't slaves," he said finally. (Roots, 69)

As it is portrayed in the story, over 300 years ago black people were taken from their native land and were treated as a property. In 1767 Kunta as the protagonist of the story along with 140 Africans were captured by white slave traders and shipped as cargo. "Then, screaming and struggling, the people were shipped toward the water, where small canoes waited to take them out to the big canoes" (Roots, 79). In Annapolis Kunta is sold to John Waller and continues his life as a slave. During the course of the story we can see his attempt to keep his African heritage. The search for the past and history is one of the most important themes in Roots.

\subsection{Subalterns Desire of Freedom}

Postcolonial thinkers like Spivak, believe our identity and subjectivity is shaped by the culture in which we live. Thus as Tyson says: "our subjectivity, then, is a lifelong process of negotiating our way, consciously and unconsciously, among the constraints and freedoms offered at any given moment in time by the society in which we live " (Spivak, 248). As Postcolonial thinkers maintain, the raw materials out of which Roots is produced are "ideological materials", that is, a system of belief and ideas (partly of the author) that values the different cultures. Central to the application of these ideological materials is their ideological representations through the main character(s) in the novel.

One of the main issues discussed by Alex Haley in Roots is that of identity, and the insecurity people have over knowing exactly who they are and what their purpose is. As an example Kunta is desperately obsessed with finding a meaning for his life and his fragmented being. In Annapolis he is sold as a slave and given the name "Toby". But he tries to escape four times. 
"You--you Toby!" Kunta didn't understand, and his face showed it, so the black one kept jabbing him and saying the same thing over and over. When Kunta continued to stare at him dumbly, the black one began jabbing at his own chest. "Me Samson!" he exclaimed. "Samson!" He moved his jabbing finger again to Kunta. "You To-by! Toby. Massa says you name Toby! "When what he meant began to sink in, it took all of Kunta's self-control to grip his flooding rage without any facial sign of the slightest understanding. He wanted to shout "I am Kunta Kinte, first son of Omoro, who is the son of the holy man Kairaba Kunta Kinte!"

(Roots, 287)

As we can see, Kunta seems to have problems to come in terms with himself as a slave. He does not approve this social discrimination. Kunta as a subaltern in this novel wants to speak, but he is beaten to death by slave catchers, proving the views of Gayatri Spivak expressed in her famous article, "Can the Subaltern Speak?"

Kunta as a Subaltern is unhappy with his present condition. Therefore, he tries to find the truth about the past and rebel against whites but after his last attempt to scape he is crippled and unable to run away and rebel. He cannot escape from the history of colonization. As it is portrayed in the story he explores the past in a couple of diverse approaches. One way that he uses is through driving Dr. Waller, which allows him to receive news of the outside world.

As it is fully expressed in the story, Kunta's identity is stolen from him by power holders and he is caught in a situation that he does not know to which culture he belongs. Kunta feels a deep lack in his splited self, which according to the psychoanalyst Jacque Lacan leaves him 'incomplete', he does not see himself as complete and projects that image of incompleteness onto everything around him. These projections often come out as unclear images, especially in the Kunta's dreams. He never answers his questions about himself and his place in society.

Kunta perseveres in keeping his dreams alive, the revolt of people in Haiti which he realizes as paralleling his own attempts for freedom is so interesting for him, especially the news about Napoleon Bonaparte. He tries to pass his dream on his daughter Kizzy, who is a clever child. But unfortunately at the age of sixteen Kizzy is sold to a man named Tom Lea and he rapes her repeatedly and these rapes leads to the birth of George. As a mother Kizzy instills in her son the pride of African heritage and Kunta's dream of freedom. From Kizzy and his grandfather he inherits the desire of freedom and he determines to buy himself and his family and reunite them.

By portraying characters like Kunta, Alex Haley tries to go back to his racial past and unconsciously he is looking for his own identity. As John Parker argues "people who have not yet seen the glory of their blackness need propaganda as much, as they need food" (8)

In this novel Haley depicts the ways superior class of society are suppressing and declining the rights of the lower class, and the way whites are trying to suppress blacks. It seems that in this novel by depicting the misery of Subaltern he is trying to say the fact that it is time that the subaltern get a chance to speak, and "it is then that we can call it a truly postcolonial era" (Bayly, 99). In Roots Haley is trying to give black people their voice and guide them to destroy all bonds of the white dominated society in order to acquire an identity for themselves.

\subsection{Inferiority Complex of Subalterns}

Identity for black people as minority groups or in Spivak's word, "subalterns", is so important. As we can see in the story, the main characters of the novel are looking for a way to define them but the racist propaganda of the white men about their inferiority has affected them. As it is mentioned in the story, White people consider blacks as animals with lust to murder and sex and want the exclusion of Negroes from society. And as it is shown, White could convince black people that they are inferior and only white are right and the tragic part is the fact that some Negros form their selfimage on the base of what white racist defined for them. In The Self-Image of the Negro American, Alvin P. Poussaint argues:

The Negro male was completely emasculated, and the Negro woman systematically exploited and vilely degraded. The plantation system implanted a subservience and dependency in the psyche of the Negro that made him forever dependent upon the good will and paternalism of the white man. (350)

In 1865 slavery was abolished but Negroes stayed oppressed in white societies and sociologically and psychologically they were rejected. Negroes were considered as a second citizen and men of an inferior race. According to Alvin P. Poussaint:

In the earliest drawings, stories and dreams of Negro children there appear many wishes to be white and a rejection of their own color. They usually prefer white dolls and white friends, frequently identify themselves as white, and show a reluctance to admit that they are Negro. (352)

As it was discussed in the above paragraph, this inferiority complex has been passed to children by parents who were habituated to believe in their inferiority and hated their black skins.

"Hush!" said Bell, laughing, and went on to say that the massa then told his horrified guests that for several generations in Haiti, so much breeding had gone on between white men and slave women that there were now almost twenty-eight thousand mulattoes and high-yallers, commonly called "colored people," of whom nearly 
all had been given freedom by their French owners and fathers. According to one of the other guests, said Bell, these "colored people" invariably sought yet lighter-complexioned mates, with their goal being children of entirely white appearance, and those who remained visibly mulatto would bribe officials for documents declaring that their forefathers had been Indians or Spanish or anything but Afri- cans.(Roots, 468)

It is clear in this part of the novel that black people hate themselves and the color of their skins more than their oppressors and as it is mentioned in this part, there were some light-skinned Negroes that could elevate themselves because they believed in having more "white blood" and some of them rejected their darker brothers. Haley's Roots depicts some characters who are dominated by this system of ideas and representations and they are even scared to contemplate these ideas and stand against them. But at the same time, these characters desire to find their individuality, and personal identity.

\subsection{Strategic Essentialism}

According to Spivak Strategic Essentialism is a concept which refers "to a strategy that nationalities, ethnic groups or minority groups can use to present themselves" (qtd in G. Ritze, 193). Although strong differences may exist between members of these groups but they continue their debates and it is "sometimes advantageous for them to temporarily "essentialize" themselves and to bring forward their group identity in a simplified way to achieve certain goals or to oppose the levelling impact of global culture" (Ashcroft, 159).

During the course of the story When Kunta is sold as a slave at first he denies to accept the slave name "Toby " but gradually he finds that men are not defined under their condition and the fact that he is slave exist only under the surface. Then he tries to pass his African heritage on to his later generation. And this performance permits his descendants to see themselves as human being.

The lessons continued through the following days and stretched into weeks. To Kunta's astonishment, "he began to discover that he was becoming able not only to understand but also to make himself understood to the brown one in a rudimentary way. And the main thing he wanted him to understand was why he refused to surrender his name or his heritage, and why he would rather die a free man on the run than live out his life as a slave". (Roots, 346)

Roots is a revolutionary work through which Haley illustrates blacks' racial identity, and makes the audience to think about black identity and individuality, and the obstacles that African-Americans face in a white dominated society. Kunta as a subaltern resists oppressive social and political constructions and his actions contribute to the freedom of diverse types of subalterns.

If we consider the actions of characters like Kunta, Kizzy, George and Haley with our knowledge that power is diffused and "wherever there is power there is resistance" (Foucault, 67) we see that black characters of the story create a kind of resistance against the corrupted socio-political order in white dominated society.

For instance although Bell knows that slaves are forbidden to read, tries to read masters newspaper. Kunta begins to teach Kizzy Mandinka, although he knows it is dangerous for a Negro child. Kizzy helps a slave name Noah to run away and teaches his son George about his grandfather. George becomes an excellent rooster trainer that begins to buy the family's freedom. Tom, George's son initiates saving to buy his family and other slaves.

Haley's Roots, presents Black people as subalterns, some of them try to bring about change through resistance. But as subalterns they do not have the clear voice that members of other groups in white dominated society have. These slaves support resistance against both local and global discriminations. All the personal events in Roots are related with historical events. In this novel Haley creates a space for his black characters to narrate their own stories. In this novel the family becomes the center of the allegorical representation of the nation. Haley presents a group of characters that attempts to navigate through the history of their family at the beginning of their disasters and its consequences decades later.

\subsection{Feeling of Otherness}

The term 'Other' is "used to refer to people or things that are additional or different to people or things that have been mentioned or are known about" (Oxford advanced Learner's Dictionary 897). Negros in a white dominated society was considered as 'Other', they suffered a lot because they were placed in a society which was dominated by white biased people. In such a society they learnt to give up their black identity and consider whites as their cultural models. In other words, in such a society whites were seen as a superior model of cultural improvement and it gives them the right to discriminate other races and cultures which were seen as inferior.

In the history of the world this separation between white and black lead to racial segregation, slavery and colonization and colored became the slave to the whites and inferior to them. Even after the civil war and abolishing of slavery, whites did not accept the new situation where their ex-servants became as equal as them and they tried to legislate what they called "separate but equal" (Clack, 178). And as the result blacks were treated as Others, and considered as second class citizens. White oppression upon black people leads them to feel they are different. 
There were some black people like T.Washington who accepted the situation and some people like W.E.B Du Bois, who "wanted to challenge segregation through political action" (Clack, 178). As it was portrayed in the story black people also considered whites as Others. Although they were aware of the fact that those who kidnapped blacks from Africa and sell them to whites were 'blacks', they blamed the whites for encouraging black to betray their brothers. They believed that white were evil. This can also be a racist act toward whites by black people. One example of this racist act is when Jankeh Jallon's baby was born:

A strange pale tan color like a cured hide, and had very odd hair [as he was a result of white's rape to Jankeh Jallon after kidnapping her, but she escaped from them]... and wherever Jankeh Jallon would appear thereafter, people would look at the ground and hurry elsewhere." (Roots, 182)

When the child was born blacks felt pity for the child because his father was a white man and he was a mixed blood child and it was a shame for a black child to have a white father. As it is portrayed in the story, in such a society mixedblood children were considered as Other and had no chance to be a part of black nor the white one.

He grew so furious every time he thought about that brown one that he wished he knew enough of the toubob tongue to go and shout, “At least I'm black, not brown like you! "From that day on, Kunta wouldn't look in the direction of that hut whenever he was outside. (Roots, 341)

The answer of Kunta to the mixed-blood slave shows his racism. Since his childhood Kunta hated white and mix-blood people and when he was kidnapped the hatred reached its climax. In chapter thirty third Haley describes the way that whites hunt black slaves and the act is in a way as they are hunting animals. And when whites want to sell blacks, they describe them as animals.

Then he walked back up the line, thrusting the butt of his whip against their chests and bellies, all the while making his strange cries: "Bright as monkeys! Can be trained for anything!" Then back at the end of the line, he prodded Kunta roughly toward the raised platform. But Kunta couldn't move, except to tremble; it was as if his senses had deserted him. (Roots, 256)

This is the way that the white man describes Kunta "Bright as monkeys". All these actions make Kunta feels to be degraded. As it is described in the story, in America slaves are considered half humans and they have no rights. There are lot of rules that they have to obey.

In a white dominated society whites are considered as 'Masters' and to be a white means to be a superior human being that must be respected and blacks are considered slave and half human and animal like. In that society blacks have no identity and they have to be named after their masters and whenever the master is changed, their names changes. For example when Kizzy works for Master Hamilton, she is called Kizzy Hamilton, but when she was sold to master Lea, she became Kizzy Lea.

\subsection{Black Identity}

As it was discussed earlier, the suffering of a people who lost their identity is the dominant theme of the story. According to the Oxford dictionary, identity is "the characteristics, feelings or beliefs that distinguish people from others" (739). During the history of the world because of "racism", black people experienced so many changes in their identity construction and were discriminated and marginalized.

In order to face white racist, "black identity" became an important element for black people. As it was portrayed in the story black existence in America is rooted to the time of slavery. From the beginning of the story by the frightening stories told by elders, we learn that young people like Kunta were hunted and taken away by white people in order to be used as a slave. African-Americans consider themselves as forced immigrants.

After arriving at Virginia, Kunta is astonished to find that other black speak English, practice Christianity and accepted the fact that they are slaves. Could it be? Had he heard an Afri- can speaking toubob? Was there a slate down there among them? Kunta had heard that toubob would often betray their black traitor helpers and throw them into chains. After the toubob had gone on down to the level below, scarcely a sound was heard on Kunta's level until they reappeared with their emptied tub and climbed back up outside, closing the hatch behind them. (Roots, 212)

At first Kunta tries to keep his native identity and does not accept the name Toby which was chosen by his white masters. But step by steps he learns to speak English and step by step he discovers that he is forgetting his native language. At the time of marriage he finds it problematic to agree to take the African- American ritual and when Kizzy was born he resisted having his daughter baptized.

Kunta chose the name Kizzy for his daughter because it was a 'Mandika' word, by the meaning of "you stay put". He assumed that this name would protect the child from being traded. By selecting these names he efforts to save the ritual of his forefathers. 
And then slowly and distinctly, in Mandinka, he whispered three times into the tiny ear, "Your name is Kizzy. Your name is Kizzy. Your name is Kizzy. "It was done, as it had been done with all of the Kinte ancestors, as it had been done with himself, as it would have been done with this infant had she been born in her ancestral homeland. She had become the first person to know who she was. Kunta felt Africa pumping in his veins--and flowing from him into the child, the flesh of him and Bell-- as he walked on a little farther. (Roots, 461)

In many ways Kunta tries to keep his African heritage and Identity. As it was mentioned in the paragraph above when the name Kizzy was chosen he felt as if the infant has been born in his ancestral homeland. And Kunta felt Africa pumping in his veins. As we can see later in the story, Kizzy learns many 'mandika' words from his father but at the age of sixteen she was sold because she has helped another slave to escape. But during the course of the story her attempts to keep her African pride and her black identity is clear. She wanted to feel safe by protecting her ancestor's rituals, culture and traditions.

After civil war slavery was banished but as it was portrayed in the memories of young Haley the grandson of the family, it stayed alive in the memory of the black people. "A collective memory is a form of remembrance that grounded the identity-formation of a people" or as some scholars suggested a "cultural trauma". (Eyerman, 1)

Alexander Haley as an African-American writer used autobiography to express his family experience through narrative. In this story he shows the way that Africans were kidnapped to bring them to America and the way that American culture was imposed on them and the way that blacks tried to keep their identity in a white dominated society. According to Athey "For the contemporary people and critics, the re-going of the roots provides a "deracination", however, the presenting of the point of view of a slave who is criticizing his master would make another option to the novel. (170)

The problem of black identity is discussed everywhere in the story by remembrance of Haley's grand parents and their African heritage. As it is presented in the story black Africans try to keep their traditions in different ways. They even recognize each other through physical appearances like tattoo. Some blacks like Kunta are so proud of their African heritage and dislike white people. Here is the part that shows his pride of their beauty.

After seeing the hungry way the toubob on the great canoe had lusted after black women, he was amazed to see that the toubob had women of their own; but looking at this specimen, he could understand why they preferred Africans. (Roots, 243)

He praises the blackness of African women and like his father believes "the more blackness a woman has the more beautiful she is" (Roots 57). Kunta is also so proud of his African name and African traditions and in various ways tries to keep them. When he was a child his grandfather used to tell him about the history of their nation and in a same way he tells his daughter about Africa in order to preserve their history. He wants his story to be told to his grandchildren as a way to keep their tradition of Africa and their black identity.

\section{Conclusion}

By considering the postcolonial aspects of Alex Haley's Roots in the light of Spivakian postcolonial theories, this paper analyses how author deals with identity of the Black American who are at the margins of society or in Spivakian word subalterns. By treatment of black characters as the subaltern in his novel, Haley shows their pitiable position in the white society. Roots is a story about the right of black people in a biased white society and the subsequent of the division of people through the race and the color of their skins which pollutes the beauty of the natural world.

All through the history, Negro-Americans as subalterns were treated like outsiders within the white society. Because of their black race and culture, they were forced to leave their homeland for slavery in the United States. As we can see Alex Haley's Roots is the history of black slaves whose identities were stolen from them. Black people have been always measured as servants and inferior to whites because of the white's power in America through centuries over the blacks. By portraying characters like Kunta, Alex Haley tries to go back to his racial past and unconsciously he is looking for his own identity. In this novel Haley depicts the ways superior class of society are suppressing and declining the rights of the lower class, and the way whites are trying to suppress blacks. It seems that in this novel by depicting the misery of Subaltern he is trying to say the fact that it is time that the subaltern get a chance to speak.

\section{References}

Alvin F. Poussaint. (2000). The Self-Image of the Negro American. New York: Penguin. 1965.

Ashcroft, Bill, Gareth Griffiths and Helen Tiffin. Post-colonial Studies: The Key Concepts. London: Routledge.

---. (2002). The Empire Writes Back: Theory and Practice in Post-colonial Literatures. 2nd ed. London: Routledge.

Athey, Stephanie. (1999). Poisonous Roots and the New World Blues: Rereading Seventies Narration and Nation in Alex Haley and Gayl Jones. Narrative: Multiculturalism and Narrative, Vol.7, No.2, (May), pp: 169-193. PDF http://www.jstor.org/stable

Clack, George. (2005). Outline of U.S History. U.S Department of State. Bureau of International Information Programs. PDF. http://usinfo.state.gov/ 
Gonzales, Doreen. (1994). Alex Haley: Author of Roots. Hillside, NJ: Enslow, 1994.

Gramsci, Antonio. (2004). Selections from the Prison Notebooks of Antonio Gramsci. Trans. and ed. Quintin Hoare and Geoffrey Nowell Smith. Chennai: Orient Longman.

Haley, Alex. (2007). Roots: The Saga of an American Family. NY: Vanguard.

Balon, R.E. (1978). The Impact of Roots on a Racially Heterogeneous Southern Community. J of Broadcasting, 299307.

McAfee, R. Preston, and John McMillan. (1989). “Government Procurement and International Trade.” Journal of International Economics 26.3: 291-308.

Sharp, J. Geographies. (2008). Of Postcolonialism. London: SAGE Publications.

Spivak, Gayatri. (1988). "Can the subaltern speak?" Marxism and the Interpretation of Culture. Oxford: Oxford University Press. 271-313

---. (1989). "In Other Words: Essay in Cultural Politics.” 1981. New Yourk. Penguin.

---. (1996). "Reading Spivak”. The Spivak reader: selected works of Gayatri Chakravorty Spivak. Routledge. pp. 1-4.

Tyson, Lois. (2006). Critical Theory Today, A User-Friendly Guide. 2th ed. New York: Routledge.

Young, Robert. (2001). Postcolonialism: An Historical Introduction, Oxford: Blackwell Publisher Inc. 